\title{
Performance of Young Sheep Fed Maize Bran and Groundnut Hay Supplemented with Sodium Chloride
}

\author{
Muhammad Alfa $^{1, a^{*}}$, Umar Aliyu $^{2, b}$, Jude Nwafor Eze ${ }^{1, \mathrm{c}}$, Elisha Zhiri Jiya ${ }^{3, \mathrm{~d}}$, \\ Isah Gbodo Muhammad ${ }^{4, e}$ \\ ${ }^{1}$ Farming System Research Programme, Research Outreach Department, \\ National Cereals Research Institute, P.M.B.8, Badeggi, Nigeria. \\ ${ }^{2}$ Director, Research Outreach Department, National Cereals Research Institute, \\ P.M.B.8, Badeggi, Nigeria. \\ ${ }^{3}$ Animal Production Department, School of Agriculture and Agricultural Technology, \\ Federal University of Technology, Minna. Nigeria. \\ ${ }^{4}$ Deen, School of Vocational Education, College of Education Niger State, Minna. Nigeria. \\ aalfanma63@yahoo.com, baliuma77@yahoo.com, judnwafor@yahoo.com, dez_jiya@yahoo.com, \\ isagbodo@gmail.com
}

Keywords: Sodium chloride, Maize bran, Groundnut hay, Yankasa rams.

\begin{abstract}
This study was conducted to assess the effect of common salt supplementation on the performance of young sheep fed maize bran and ground nut hay as basal diet. It covered a period of 12 weeks. A $3 \times 3$ Latin square design was employed in the experiment. The daily feed intake, daily body weight gain and feed conversion efficiency were measured during the experimental period. Results showed that inclusion of common salt at the level of $1.0 \%$ of feed had no significant effect on feed intake ( $>0.05)$. There was depressed feed intake as quantity of salt increased from $0.0 \%$, to $0.5 \%$ and $1.0 \%$. The best mean average daily weight gain of $43.35 \%$ was obtained with the $1.0 \%$ salt treatment. Salt inclusion up to $1.0 \%$ level in sheep ration, had no adverse effect on performance, it rather gave a more favorable weight gain and better feed conversion efficiency. These findings are of very practical significance in sheep fattening, especially for farmers in rural setups.
\end{abstract}

\section{Introduction}

Nigeria was reported by [1,2] to have a sheep population of about 22 million heads, which were entirely of the hairy thin tailed, West African long legged type, kept primarily for their meat and skin. These include the Uda, Balami, Yankasa and West African Dwarf sheep. Sheep (Ovine aries) plays an indispensable role in the traditional agriculture and largely subsistence economy, the sub-sector contributes about $15.3 \%$ of the total agricultural sector [3]. The bulk of these animals are kept by rural farmers under extensive management system. Beside meat, sheep are valuable assets to the local populace to whom the small stock is an integral part of the family unit and emergency source of fund. Sheep is also featured predominantly in the socio-cultural functions like ceremonies and religious feast. Sheep and in particular rams, are favorite animals, during Muslim festivals of Idel-kabir, by the fact that, fattened rams command very high market prices during the festival. Small ruminants (Sheep and goat) contribute $35 \%$ of the national meat supply in Nigeria [4]. The output of sheep and goat meat in Nigeria was estimated by [5] to have reached 163000 tonnes in 1980. He pointed out that, sheep and goats, are increasingly becoming a major source of animal protein in the country. The purpose of rearing sheep in Nigeria are; Source of income generation for the farmers, for sacrifice, festival, ceremonies, household consumption and security against crop failure [6] Increased sheep population, could contribute towards improvement in human nutrition and is particularly significant in preventing protein malnutrition.

Nutrition and sheep performance: Inadequate nutrition is a major limitation to the productivity of sheep in Nigeria and other countries within the arid and semi-arid regions of sub-Saharan West Africa. Feeds of good quality and quantity constitute the greatest input in Animal production, not 
only for production of milk, meat or eggs, but also for growth and body maintenance. High plane of nutrition was noted by [8] to foster greater daily gain to puberty, with age at puberty significantly lower than on a moderate plane of nutrition The cheaper the feed source without sacrificing quality, the better the returns for the farmer. Feeding must provide the sheep with the ingredients it need to live, function and reproduce, while meeting up with the required body weight [9]. Sheep have a way of converting poor food in to desirable products. None of the domesticated animals surpass sheep in their ability to utilize pastures. The feed conversion ratio (FCR) or feed conversion efficiency (FCE) is a measure of an animal's efficiency in converting feed mass into increased body mass. Specifically FCR is the mass of the food eaten divided by the output, all over a specified period. Thus feed conversion efficiency is $\mathrm{kg}$ body mass gain per $\mathrm{kg}$ feed intake (or, in the case of dairy animals, $\mathrm{kg}$ milk solids per $\mathrm{kg}$ feed intake). By way of example, sheep and cattle need more than 8 $\mathrm{kg}$ of feed to put on $1 \mathrm{~kg}$ of live weight, their ratio is thus 8:1. Being a ratio, FCR is dimensionless, i.e. there is no measurement units associated with FCR. ). Other things being equal, FCR tends to be higher for older lambs (e.g. 8 months) than younger lambs (e.g. 4 months) [10]. Good green pastures and legume hays (groundnut tops, soybean and cowpea hay) are excellent and practical sources of protein for sheep. It was suggested by [11] that a free choice source of water, salt, and minerals should be available to rams at all times. He observed that when a sufficient quantity of forage is available, sheep are able to meet their nutrient requirements from forage alone along with a supplemental source of salt and minerals. When additional energy and protein are required, corn and soybean meal commonly form the basis of the grain portion of the diet.

Common salt as management tool for sheep: Common salt is a condiment as well as nutrient [12]. As a condiment salt serve a physiological need, in that it stimulate salivary secretion and promotes the action of diastase enzymes. Sodium was reported by [13] to occur primarily in extracellular fluids and bones while chlorine is found within cells, in the body fluids, in gastric secretions such as hydrogen chloride, and in the form of salt. He pointed out that Sodium (Na) and chlorine (cl) serve many functions in the body. They maintain osmotic pressure, regulate the acidbase balance, and control water metabolism in tissues. When the animal is deprived of salt, feed consumption and water intake usually decreases. Milk production and growth rate was also reduced coupled with inefficiency in feed use. Sheep, under normal condition, derive salt either from the food they eat or from drinking water. Common salt (sodium chloride) is one of the essential nutrients in the rations of sheep and lambs, while its proper provision makes for a more profitable and satisfactory sheep husbandry. Sheep must have a free-choice supply of clean, fresh water [11].

Salt tolerance of sheep: Sheep and cattle are able to tolerate $7-10 \%$ of sodium chloride in the diet before feed intake is depressed [14]. Sodium chloride requirement for adult sheep is $3 \mathrm{~g} / \mathrm{Kg} \mathrm{DM}$ or $2 \mathrm{~g} / 10 \mathrm{KgLW}$ as reported by [9]. However [15 and 16] indicated that, excessive intake of salt depress feed intake, digestibility and the growth of ruminants, while moderate levels have beneficial effects on production. Better rates of live weight gain were obtained on rams supplemented with common salt, compared to those on the control diet with no salt supplementation [17]. Dry lot tests showed that lambs consumed approximately 5 to $10 \mathrm{~g}$ of salt daily [18]. Addition of 1.2 to $2.6 \mathrm{~g}$ of sodium per day (as sodium chloride) to the diet of very thin wethers, fed a low-sodium grain diet increased growth rate [19]. They stated that the sodium requirement was greater than $0.9 \mathrm{~g} / \mathrm{d}(0.06$ percent of the diet). From balance data, [20] estimated the sodium requirements for the maintenance of wether lambs to be $1.01 \mathrm{~g} / \mathrm{d}(0.18$ percent of the diet). When adding salt to mixed feeds, it is customary to add 0.5 percent to the complete diet or 1.0 percent to the concentrate portion [21]. It was concluded by [22] that the dietary salt requirement for growing lambs ranged between 0.33 and 0.43 percent of the air-dry ration ( 90 percent dry matter). Salt should be fed in the loose form to allow for better intake [23]. The level of other minerals in the diet also affects mineral requirements. Too little or too much of one mineral can render another one deficient or toxic to the animal. As indicated by [24], Dry matter (DM) intake is an important consideration in formulating sheep rations. They pointed out that severely restricted DM intake often results in a 5 to 10 fold increase in salt and mineral intake, when minerals are offered free choice. They maintained that, feeds excessively high 
in fiber or water may restrict nutrient intake. Salt can be used as a management tool to gather sheep, aid in herding or to improve the range or pasture utilization. Common salt contains $39.34 \% \mathrm{Na}$ and $60.66 \% \mathrm{cl}[25]$

Justification and objective: Maize bran is $40 \%$ similar in composition to the whole grain [9]. It is relatively cheaper than whole grain and encounters almost no competition for consumption by man. Maize bran is consumed reasonably well by sheep, goat poultry and other classes of livestock. Groundnut hay also served as source of protein for the experimental sheep. Sheep like other classes of livestock, require common salt for proper body functions and growth. It is therefore necessary to include it in the diet of sheep at specific quantity, for maximal utilization and efficiency of basal diets. This work was aimed at assessing the performance of young sheep fed maize bran and groundnut hay supplemented with different level of common salt.

\section{Materials and Methods}

Description of experimental animals: Yankasa rams were used in conducting this research work, due to their availability and adaptability to the study area. The breed is considered the most numerous amongst the various breeds of sheep in Nigeria, most especially in the Northern part of the country where the trial was conducted. Yankasa sheep are of medium size, hairy and has a predominantly white color with black patches around the eyes, nozzles and hooves. The mature live weight is about $40 \mathrm{Kg}$ [7]. While rams have curved horns, they are short or totally absent in ewes. At birth, the male weighs about $3.5 \mathrm{Kg}$ while the female weighs about $4 \mathrm{Kg}$. A total number of $18 \mathrm{rams}$, about 12 months from delivery, with average live weight of $13 \mathrm{~kg}$ were used for this research work. The rams were purchased from Beji market near Minna. The trial was conducted at the animal farm unit of Federal University of Technology, Minna between $10^{\text {th }}$ August, 2015 and $1^{\text {st }}$ November, 2015.

Management of experimental animals: The animals were bathed, treated against external parasites and dewormed with Rintal dewormer. The rams were allotted according to body weight in to three treatment groups with six animals per treatment. The experimental animals were housed in the experimental pen with concrete floor. Prior to introduction of the animals in to the experimental pen, the pen was swept, washed and kept clean of any foreign materials. A period of fourteen days was allowed for adjustment to the environment and experimental feed, before commencement of measurements. The animals were fed maize bran and groundnut hay as basal feeds, while graded levels of sodium chloride were mixed as mineral supplements amongst the experimental diets. A 3 $\times 3$ Latin square design was employed in the experiment. The experiment covered a period of 12 weeks, excluding two weeks adjustment period preceding commencement of the experiment. Each treatment covered three weeks with one week adjustment period between treatments. Rams under each treatment were fed the same quantity of basal feed, on daily bases. This was compounded to meet the $15 \%$ crude protein requirement of sheep per day at $5 \%$ body weight.

The whole experiment went through three corresponding periods numbered I, II and III. Six animals were allotted to each of the three treatments labeled T1, T11 and T111. During period 1, animals under each of the three treatments $\mathrm{T} 1, \mathrm{~T} 11$ and $\mathrm{T} 111$ received $0.0 \%, 0.5 \%$ and $1.0 \%$ of common salt respectively, in relation to the quantity of feed served to them. While during period 11 , salt was provided at $0.5 \%$, to $\mathrm{T} 1,1.0 \%$ to $\mathrm{T} 11$ and $0.0 \%$ to animals in $\mathrm{T} 111$. The experiment was rounded up at Period 111 where $1.0 \%, 0.0 \%$ and $0.5 \%$ salt was served for animals in T1, T11 and T111 respectively. As indicated in Table 1, each of the three treatments were featured in the three periods respectively, while performance result of the animals (table 3) were reflections of the outcome of the three treatments during periods 1,11 , and 111 . Hence the actual impacts of salt treatments at $0.0 \%, 0.5 \%$ and $1.0 \%$ over the three periods were obtained through Statistical analysis using ANOVA (26). 
Table 1. Allocation of treatments to graded levels of sodium chloride using the 3 X 3 Latin Square Design for yankasa ram.

\begin{tabular}{|l|l|l|l|}
\hline \multirow{2}{*}{ PERIODS } & \multicolumn{3}{|c|}{ TREATMENTS } \\
\cline { 2 - 4 } & T1 & T11 & T111 \\
\hline \multicolumn{4}{|c|}{ SODIUM CHLORIDE (\%) } \\
\hline I & 0.0 & 0.5 & 1.0 \\
\hline II & 0.5 & 1.0 & 0.0 \\
\hline III & 1.0 & 0.0 & 0.5 \\
\hline
\end{tabular}

Measurements: Weekly data on weight gain as well as daily records of feed consumption were collected during treatment and adjustment periods. Left overs of feeds served the previous day were collected the following morning and weighed, to obtain differences of daily consumption. Both the initial and final live weights of the experimental animals were taken on weekly bases, per treatment, per period. Samples of the feed mixture were also taken weekly for laboratory analysis (Table 2). Laboratory analysis were conducted to determine proximate composition of sampled feeds in terms of Dry matter (DM), Crude protein (CP), Crude fibre (CF), Ether extract (EE), Nitrogen Free Extract (NFE), calcium (Ca), Sodium (Na), chlorine (cl), phosphorus (P), Metabolic energy (Me), kilocalories $(\mathrm{kcal})$. The records obtained from weekly weight readings of periods 1,11 and 111 across T1, T11and T111 were statistically analysed. Statistical analysis was conducted by using analysis of variance (ANOVA) [26]. The levels of significance between results were tested by Least Significance Difference (LSD) in line with [27, 28 and 29].

Table 2. Proximate Composition of Feeds (\%) for yankasa ram.

\begin{tabular}{|l|l|l|l|l|l|l|l|l|l|l|l|}
\hline \multicolumn{10}{|c|}{ Nutrient } \\
\hline
\end{tabular}

$a, b$-means in the same column with different superscripts are significantly different $(p<0.05)$ $\pm=$ Standard deviation

$\mathrm{GNH}=$ Ground nut hay: $\mathrm{MB}=$ Maize bran.

\section{Results and Discussion}

Table 3 gives a summary of performance characteristics of animals across all the three periods of the trial. Highest mean daily feed intake of $658.35 \mathrm{~g}$ was obtained from animals allotted $0.0 \%$ salt in treatment 1 (control group), while treatment 111 animals with highest salt inclusion level of $1.0 \%$ had least mean daily feed intake of $642.95 \mathrm{~g}$. There was however no significance difference in mean daily feed intake among the treatments. Conversely, those animals on $1.0 \%$ salt inclusion level with least feed intake had the highest mean daily weight gain of $43.35 \mathrm{~g} / \mathrm{day}$, followed by those with $0.0 \%$ level of salt inclusion, while the treatment 11 animals with 0.5 inclusion level had the least mean daily weight gain of $16.67 \mathrm{~g}$. The mean daily weight gain of $43.35 \mathrm{~g}$ obtained from treatment 111 was significantly different from those of $22.62 \mathrm{~g}$ and $16.67 \mathrm{~g}$ obtained from treatment 1 and 11 respectively. The values obtained for Feed conversion efficiency (that is feed/gain or conversion rate) was $100.50,40.57$ and 20.44 for treatments 11 , 1 , and 111 respectively. This indicated that animals in treatment 111 had better feed conversion efficiency, since the lower the value the better the inclusion level. Animals in the control group with $0.0 \%$ salt also had a better conversion rate than those with $0.5 \%$ salt. Treatments 1 and 111 had significant rate of conversion, compared to treatment11. 
Hence, results from Table 3 are indicators of cumulative responses obtained from the animals during periods 1,11 and 111, at various trial levels of 0.0, 0.5 and 1.0 represented as $\mathrm{T} 1$, $\mathrm{T} 11$ and $\mathrm{T} 111$ respectively.

The least consumption obtained from animals with highest level of salt supplementation is contrary to the report by [12 and 30], that when an animal is deprived of salt, feed consumption and water intake are usually decreased. However, [30] reported that sheep under natural conditions derive common salt either from the food they eat or from drinking water, while [15] reported depressed feed intake as a result of high level of salt in the feed of animals. The sodium chloride contained in either the basal feed or drinking water could have been sufficient to influence intake, even at zero percent inclusion level obtained in $\mathrm{T} 1$ throughout the experimental periods. The high intake of the salt-free diet could also be because of the tendency of sheep to eat as much feed as they want as pointed out by [31].

Results obtained from table 3 indicated both the initial and final live weights of the experimental animals in the course of the experiment. However it needs to be appreciated that, these are cumulative weights obtained from the animals at various readings across the experimental periods and treatments. The readings were not for any particular group of sheep as it may appear, while the mean daily weight gains were statistically analyzed through ANOVA. The highest mean daily weight gain of $45 \pm 8.96 \mathrm{~g}$ was obtained from animals under $1.0 \%$ salt treatment. The value was significantly different from what obtained in $0.0 \%$ and $0.5 \%$ salt treatments. This result is in line with [17] where daily weight gain of sheep supplemented with sodium chloride was much better than those not supplemented. The increase in body weight due to higher intake of salt could be attributed to among other functions, the regulatory role of common salt in acid-base balance as reported [13].

Table 3: Performance characteristics of sheep fed graded levels of sodium chloride.

\begin{tabular}{|l|c|c|c|}
\hline Characteristics & $\begin{array}{c}\text { T1(Prd1 11 111) } \\
0.0 \% \text { salt } \\
\text { S.E.M }\end{array}$ & $\begin{array}{c}\text { T11(Prd 1 11 111) } \\
0.5 \% \text { salt } \\
\text { S.E.M }\end{array}$ & $\begin{array}{c}\text { T111(Prd1 11 111) } \\
1.0 \% \text { salt } \\
\text { S.E.M }\end{array}$ \\
\hline $\begin{array}{l}\text { Initial } \\
\text { Live weight (g) }\end{array}$ & 12000.00 & 14500.00 & 13000.00 \\
\hline Final & 14500.00 & 16500.00 & 15550.00 \\
Live weight (g) & $658.35^{\mathrm{a}}$ & $654.47^{\mathrm{a}}$ & $642.95^{\mathrm{a}}$ \\
\hline Mean Daily & $( \pm 19.31)$ & $( \pm 30.92)$ & $( \pm 26.99)$ \\
Feed Intake (g) & $22.62^{\mathrm{b}}$ & $16.67^{\mathrm{b}}$ & $43.35^{\mathrm{a}}$ \\
& $( \pm 2.39)$ & $( \pm 2.39)$ & $( \pm 8.96)$ \\
\hline Mean Daily & $40.57^{\mathrm{b}}$ & $100.50^{\mathrm{a}}$ & $20.44^{\mathrm{b}}$ \\
Weight Gain (g) & $( \pm 12.95)$ & $( \pm 23.79)$ & $( \pm 0.57)$ \\
\hline Feed Conversion & & & \\
Efficiency & & & \\
\hline
\end{tabular}

Values in parenthesis are the standard Error of Means (S.E.M.) for the values immediately above. Means in the same row having the same letters are not significantly different $(p>0.05)$

$($ Prd $1,11 \& 111)=$ periods $1,11 \& 111$

As evident in table 3, sheep in treatment 111 allotted to $1.0 \%$ salt trial had best conversion rate with significant difference compared to the other two treatments. Hence this experiment showed that least feed intake and highest weight gain was obtained from animals on $1.0 \%$ salt treatment. Salt inclusion level of $1.0 \%$ also gave the best feed conversion rate. Result of this study had indicated lower feed intake from sheep on $1.0 \%$ salt and better feed utilization as evidenced by better feed conversion (table 3). As pointed out by [32], the objective of feed supplementation is to increase efficiency of utilization of nutrients. It was asserted by [30] that sheep are more tolerant of salt than any other animal and can tolerate a salt concentration of $1 \%$ or more provided there is only a small proportion of other soluble salt. The above assertion is a clear support to the result obtained by this 
work. In view of this and in the light of the result obtained from this study, one could safely conclude that salt could be added to sheep ration up to one percent level without any deleterious effect. In fact 1.0\% level of salt inclusion should enhance efficiency of feed utilization.

\section{Conclusion}

The result of this experiment showed that although high level of salt inclusion $(1.0 \%)$ had a limiting effect on feed consumption, but not significantly, it however enhanced better feed utilization as evidenced by better feed conversion. This level of salt inclusion, also gave highest mean daily weight gain of $43.45 \pm 8.9 \mathrm{~g}$, hence, the inclusion of common salt up to $1.0 \%$ in the diet, with an adequate level of protein and energy source should therefore bring about better growth rate and better utilization of feed even at low level of intake. This is an important economic use of feed resources. It is also an economic tool for sheep fattening both for the attainment of market weight and animal shows. It is also an important market value for feed companies that partake in preparation of sheep feed, especially for enhancement of fattening. It provides an economic tool for sheep fattening so as to attain desired body weight for festivals with achievement of high economic returns.

\section{References}

[1] A.S.S.S. Umar, Financial analysis of small scale beef fattening enterprise in Bama Local Government Area of Borno State. An unpublished M.Sc. Thesis, Department of Agricultural Economics and Rural Sociology, ABU, Zaria, 2007.

[2] RIM, Nigerian National Livestock Resource Survey.vol 11. Report by Resource lnventory and Management Limited (RIM) to FDLPCS, Abuja, Nigeria, 1992.

[3] J.A. Mbanasor, The future of livestock in Nigeria, In: S.N. Ukachukwu et al. (ed.), Animal Production in the New Millennium. Challenges and Options, 8-16, Proceedings of the 25th Animal Conference held at the Michael Okpara University of Agriculture Umudike, Nigeria, 2000 .

[4] D.V. Uza, S.O.A. Abubakar, U.H. Ahmed, Transferable Technologies for Enhancing SmallHolder Livestock Production. Onari printing and publishing company Ltd., Nigeria, 1999, pp. 39-57.

[5] J. McClintock, What causes supply levels from African Livestock Sectors to change? ILCA's LPU working paper no. 2. (1983).

[6] P.O. Ozung et al., The Potentials of Small Ruminant Production in Cross River. Rain Forest Zone of Nigeria: A Review, Continent. J. Anim. Vet. Res. 3(1) (2011) 33-37.

[7] O.A. Osinowo, Potentials for small ruminant production in Nigeria, Paper presented at the $15^{\text {th }}$ Annual Conference, Nigerian Society for Animal Production, 1990.

[8] D.M. Allen, G.E. Lamming, Some effects of nutrition on the growth and sexual development of the ewe lambs, Journal Agricultural Science. 57(01) (1961) 87-95.

[9] J. Charray, J.M. Humbert, J. Levif, Feeding Manual of Sheep production in the humid tropics of Africa. Published by Technical Centre for Agricultural and Rural Cooperation, Lome, Togo, 1992, pp. 60-69.

[10] National Research Council, Nutrient requirements of small ruminants. National Academies Press, 2007, p. 362.

[11] S.H. Umberger, Feeding Sheep. Virginia Cooperative Extension, Virginia Tech. Publication. (2009) 410-853.

[12] A.L. Maynard, The animal and its body, Animal Nutrition. 7 (1983) 17-18. 
[13] E.J. Underwood, The Mineral Nutrition of Livestock, Commonwealth Agricultural Bureaux, Slough, UK, 1981.

[14] National Research Council. Mineral Tolerance of Animals, The National Academics Press, Washington, 2005.

[15] J.A. Hemsley, J.P. Hogan, R.H. Weston, Effect of high intakes of sodium chloride on the utilization of a protein concentrate by sheep, Australian Journal of Animal Science. 26(7) (1975) 715-727.

[16] A.D. Wilson, The intake and excretion of sodium by sheep fed on species of livestock: Problems and Prospects, Nairobi, Kenya, 1966, pp. 277-280.

[17] T. Panggabean, A. Little, Effect of supplementary Sodium and Selenium on the performance of rams, Tropical Agriculture. (1987) 200-211.

[18] D.A. Denton, Salt appetite, Nutrition abstracts and reviews. 39)4z) (1969) 1043-1049.

[19] C.L. Mcclymont et al., Sodium chloride supplementation of high-grain diets for fattening Merino sheep, Aust. J. Agric. Res. 8 (1957) 83.

[20] T.J. Devlin, W.K. Roberts, Dietary maintenance requirement of sodium for wether lambs, J. Anim. Sci. 22 (1963) 648.

[21] R.M. Jordan, H.E. Hanke, Effect of mineral additions to trace mineralized salt on daily intake of salt and minerals, Proc. 54th Sheep and Lamb Feeders Day, 1982, p. 182.

[22] I.T. Hagsten, W. Perry, J.B. Outhouse, Salt requirements of lambs, J. Anim. Sci. 40 (1975) 329.

[23] Alberta, Salt and Minerals for Sheep, Agriculture and Forestry, Africa, Published by Technical Centre for Agricultural and Rural Cooperation, Lome, Togo, 2013, pp. 60-69.

[24] National Academic Press, Sixth Revised Edition, Nutrient Requirements of Sheep, 1985.

[25] A.O. Aduku, Tropical Feedstuff Analysis Table, 1993.

[26] M.L. Thomas, F.H. Jackson, Methods of Statistical Analysis. Agricultural Experimental Design and Analysis. (1978) 10-14.

[27] A.S Matsoukis, I. Tsiros, A. Kamoutsis, Leaf area response of Lantana camara L. subsp. camara to plant growth regulators under different photosynthetic flux conditions, HortScience 39(5) (2004)1042-1044.

[28] H.K. Ngugi, J.R. Schupp, Evaluation of the risk of spreading fire blight in apple orchards with a mechanical string blossom thinner, HortScience. 44(3) (2009) 862-865.

[29] I. Ajiji, H.D. Nyako, L.Y. Guluwa, Performance of yankasa rams fed graded levels of Moringa oleifera leave meal, Journal of Biology, Agriculture and Healthcare. 5(20) (2015) 95-97.

[30] B.A. Fajemisin, Mineral and Vitamin requirement of sheep and goat, In : Nigerian sheep and goat manual. National Animal Production Research Institute, Small Ruminant Research Programme Workshop, 1990.

[31] R.M. Gatenby, Importance and characteristic of sheep and goat. Sheep Productio, Published by Technical Centre for Agricultural and Rural Cooperation, Lome, Togo, 1990.

[32] T.J. Kempton, Role of feed supplement in the utilization of low protein roughage diet by sheep, World Review of Animal Production. 18(2) (1982) 7-15. 